Article

\title{
Combustion and Emission Characteristics of Coconut-Based Biodiesel in a Liquid Fuel Burner
}

\author{
Muhammad Syahiran Abdul Malik ${ }^{1}$, Ashrul Ishak Mohamad Shaiful ${ }^{2}$, \\ Mohd Shuisma Mohd. Ismail ${ }^{1}$, Mohammad Nazri Mohd Jaafar ${ }^{1}$ and \\ Amirah Mohamad Sahar ${ }^{3,4, *}$
}

1 Department of Aeronautical, Automotive and Ocean Engineering, Faculty of Mechanical Engineering, Universiti Teknologi Malaysia, 81310 Johor Bahru, Johor, Malaysia; msyahiran4@gmail.com (M.S.A.M.); shuisma@fkm.utm.my (M.S.M.I.); nazri@fkm.utm.my (M.N.M.J.)

2 School of Manufacturing Engineering, Universiti Malaysia Perlis, Kampus Alam Pauh Putra, 02600 Arau, Perlis, Malaysia; mshaiful@unimap.edu.my

3 College of Engineering, Design and Physical Sciences, Brunel University London, London UB8 3PH, UK

4 Communication Section, University Kuala Lumpur, British Malaysian Institute, 53100 Gombak, Selangor, Malaysia

* Correspondence: mepgabm@brunel.ac.uk; Tel.: +60-4-988-5035; Fax: +60-4-988-5034

Academic Editor: Wei-Hsin Chen

Received: 29 November 2016; Accepted: 17 February 2017; Published: 1 April 2017

\begin{abstract}
This paper presents an investigation on the combustion performance of different Coconut Methyl Ester (CME) biodiesel blends with Conventional Diesel Fuel (CDF) under B5 (5\% CME, 95\% $\mathrm{CDF})$, B15 (15\% CME, 85\% CDF), and B25 (25\% CME, 75\% CDF) conditions. The performances of these fuels were evaluated based on the temperature profiles of the combustor wall and emission concentration of Oxides of Nitrogen $\left(\mathrm{NO}_{\mathrm{x}}\right)$, Sulphur Dioxide $\left(\mathrm{SO}_{2}\right)$, and Carbon Monoxide $(\mathrm{CO})$. The fuel properties of the CME biodiesel blends were measured and compared with CDF. All tested fuels were combusted using an open-ended combustion chamber at three different equivalence ratios, i.e., lean fuel to air mixture $(\Phi=0.8)$, stoichiometry $(\Phi=1.0)$, and rich fuel to air mixture $(\Phi=1.2)$, using a standard solid spray fuel nozzle. The results indicated that CME biodiesel blends combust at a lower temperature and produce less emission in comparison with CDF for all equivalence ratios. Moreover, the increase of $\mathrm{CME}$ content in biodiesel blends reduced the temperature of the combustor wall and the emission concentration. Results also proved that the utilization of biodiesel is beneficial to various industrial applications, especially in the transportation sector due to it being environmentally friendly, and serves as an alternative to petroleum diesel fuel.
\end{abstract}

Keywords: CME biodiesel blend; combustion; equivalence ratio; emission

\section{Introduction}

During the past few decades, global attention on biodiesel production and utilization has increased significantly due to the international energy crisis and fossil fuel depletion [1]. The burning of fossil fuels such as petrol, diesel, and coal are among contributors to the emission of hazardous gases such as Oxides of Nitrogen $\left(\mathrm{NO}_{\mathrm{x}}\right)$, Sulphur Dioxide $\left(\mathrm{SO}_{2}\right)$, and Carbon Monoxide (CO) into the atmosphere [2]. $\mathrm{NO}_{\mathrm{x}}$ is the binary compound of oxygen and nitrogen, which forms Nitrogen Monoxide (NO), Nitrogen Dioxide $\left(\mathrm{NO}_{2}\right)$, and Nitrous Oxide $\left(\mathrm{N}_{2} \mathrm{O}\right)$ [3]. $\mathrm{NO}_{\mathrm{x}}$ and $\mathrm{SO}_{2}$ combine with water vapors in the clouds to produce sulphuric acid $\left(\mathrm{H}_{2} \mathrm{SO}_{4}\right)$ and nitric acid $\left(\mathrm{HNO}_{3}\right)$, which fall back to the earth as acid rain. These compounds turn soil and lakes acidic and corrode building structures [4]. High concentrations of $\mathrm{CO}$ in the atmosphere cause harmful effects to human health by reducing the oxygen levels in the blood vessel delivered to body organs and tissues [5]. Biodiesel is a mono alkyl ester of long fatty acids 
derived from renewable lipid feed stocks, such as vegetable oil and animal fats, for use in compression ignition diesel engines [6,7]. Biodiesel is produced by a chemical process called transesterification, i.e., a reaction between triglycerides and alcohol to produce methyl ester and glycerol. Methyl ester is blended with diesel to produce biodiesel, while glycerol is used to produce soaps. Biodiesel can be utilized in pure form or mixed with diesel at any concentration [8]. Biodiesel blends are categorized in the designated form of "BXX", where "XX" is the percentage of biodiesel in the blend, e.g., "B60" has $60 \%$ of methyl ester and $40 \%$ of diesel fuel. Biodiesel can be produced from a variety of feedstocks such as palm oil, corn oil, waste cooking oil, and coconut oil. However, biodiesel production depends on the availability of the feedstock in any particular region. In tropical regions such as in Indonesia, Papua New Guinea and the Philippines, coconut is widely available, and hence it is cheaper for the locals to utilize biofuel from this source to generate electricity.

The research regarding other potential feedstocks of biodiesel as an alternative fuel has been done by many researchers in the past years. In 2008, Lapuerta [9] and his colleagues investigated the use of biodiesel from waste cooking oil in diesel engines and found that the emission level of $\mathrm{CO}$ was reduced but $\mathrm{NO}_{\mathrm{x}}$ emission increased as compared to that of CDF. This is somewhat different from what Canakci and Van Gerpen [10] obtained in their experiments using B20 and B100 biodiesel blends from soya bean and waste cooking oil in a four cylinder turbo-charged diesel engine. Both biodiesels emit higher $\mathrm{NO}_{\mathrm{x}}$ than $\mathrm{CDF}$, but $\mathrm{CO}$ emission showed a significant reduction. In a study conducted by Jaafar et al. [11] using refined, bleached, and deodorized palm oil (RBDPO) and biodiesel tested in an industrial oil burner with and without air staging, the formation of $\mathrm{NO}_{\mathrm{x}}, \mathrm{CO}$, and $\mathrm{SO}_{2}$ were found at most reduced by $74.7 \%, 56.9 \%$, and $68.5 \%$, respectively, compared to that of CDF. The air staging (secondary air) introduced during combustion reduced the emission concentrations even further. Again, in 2014, Jaafar and his co-workers [12] compared the combustion performance of various palm oil biodiesels with CDF in a conventional fuel burner. They found out that increasing the content of palm oil biodiesel in the fuel blend reduces the combustion temperature and emission levels of $\mathrm{NO}_{x}, \mathrm{SO}_{2}$, and CO. This finding is similar to that obtained by Ganjehkaviri et al. [13] in 2016, where various palm oil biodiesel blends with CDF were combusted in an oil burner at three different nozzle flow rates $(1.25,1.50$, and 1.75 US gal/h). All palm oil biodiesel blends had lower combustion wall temperatures than $\mathrm{CDF}$ for all nozzle flow rates and emit lower $\mathrm{NO}_{\mathrm{x}}$ and $\mathrm{CO}$ emissions.

The utilization of coconut oil-based biodiesel in tropical regions has grabbed the attention of researchers around the world to study the benefits of using biodiesel blends from coconut. Coconut oil is produced from copra, the dried flesh of a coconut commonly used in cooking and frying as well as being converted into soaps, health and cosmetic products [14]. The production of coconut oil begins with the drying of copra using heat from the sun or from burning biomass. It is then stored in a warehouse for 2 to 3 months to allow the copra to dry further. The dried copra is then transferred to a copra cleaner to remove any impurities, dirt, and foreign objects before it is broken into small pieces of about $1 / 16^{\prime}$ to $1 / 18^{\prime}$ using a high speed vertical hammer. The copra pieces are then cooked inside a steam cooker at $110^{\circ} \mathrm{C}$ for $30 \mathrm{~min}$. Then, the copra is transferred into an expeller, where it is subjected to high-pressure oil extraction using a vertical screw and a horizontal screw. The temperature during the extraction process is between $93^{\circ} \mathrm{C}$ to $102{ }^{\circ} \mathrm{C}$; between these temperatures, maximum extraction is possible and produces a light coloured oil. The coconut oil undergoes a screening process to remove entrained objects from the oil using chained mounted scrappers. Finally, it is filtered to further remove any impurities inside the oil before being stored inside a storage tank.

The total global production of coconut oil in the period between 2014 and 2015 was $3,460,000$ tonnes and came mainly from tropical region countries [15]. As illustrated in Figure 1, the Philippines accounted for $45.2 \%$ of the total oil production, followed by Indonesia at $28.2 \%$, India at $11.6 \%$, Vietnam at $4.4 \%$, Mexico at $3.8 \%$, and the rest of the world at $6.8 \%$. The average international price for coconut oil decreased from USD 1280 per tonne in 2014 to USD 1131 per tonne during June 2015 and further declined to USD 1039 in August 2015 [15]. The World Bank Commodities Price Forecast predicted that the average price of coconut oil will be USD 1112 in 2016, and it is expected to 
constantly decrease by USD 13 for the next three years. The decrease in the international market price of coconut oil will give tremendous effect to coconut oil-based industries in Pacific Island countries such as Fiji, Papua New Guinea, and the Solomon Islands, as these countries contribute a substantial amount to the total production of coconut oil in the world. These countries rely on the traditional method to produce coconut oil, which requires a large number of low-salaried workers to run the production, i.e., from collecting to cutting and finally drying the coconut flesh. The reduction in the coconut oil price will affect labour cost rates, thus choking the related industries to become almost extinct [16]. Hence, utilizing coconut oil as biodiesel provides a new means for these island countries to generate their economy as well as their own power supply.

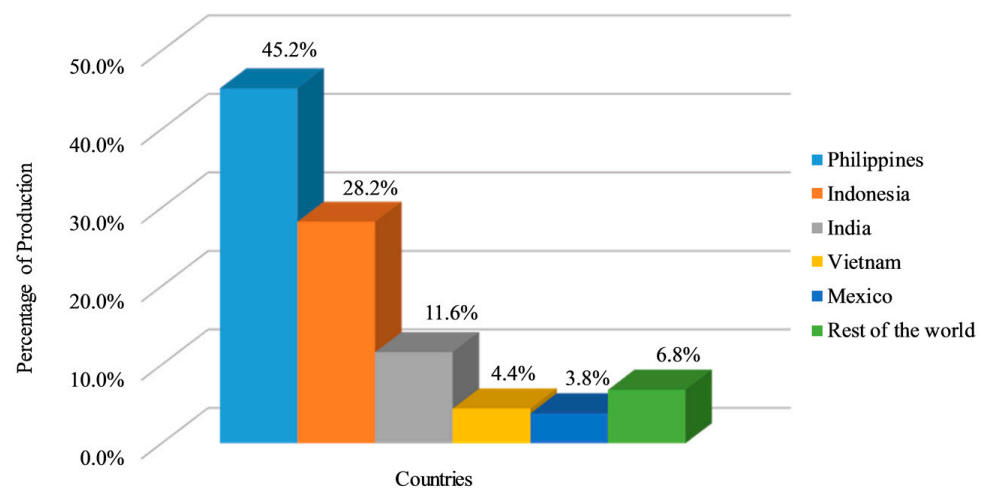

Figure 1. Production of coconut oil from different countries in 2014 to 2015.

Coconut oil-based biodiesel can be used in diesel engines without significant modifications. Raghavan [14], Saifuddin et al. [17], Suryanto et al. [18], and Llamas et al. [19] found that coconut oil is majorly made up of saturated medium chain fatty acids, especially lauric acid and myristic acid. Moreover, coconut oil solidifies at temperatures of less than $24^{\circ} \mathrm{C}$ and has a lower energy content than diesel. Another advantage of using coconut oil is that it possesses a high cetane number, which enables it to ignite faster than other plant oil biodiesels. However, the viscosity of coconut oil is very high, which can cause poor volatilization in the fuel injector system and a poor spray pattern. To overcome this high viscosity, coconut oil is usually heated using a heat exchanger before being sprayed into the combustion chamber. In another research, Giles [20] found out that coconut-based biodiesel can combust properly above $500^{\circ} \mathrm{C}$ in a compression ignition diesel engine. He showed that coconut-based biodiesel would have shorter ignition delay, equivalently close to diesel at this temperature. The shorter combustion delay will avoid carbon deposition on the nozzle and piston valves as well as reducing the formation of $\mathrm{NO}_{x}$ and $\mathrm{CO}$. Other researchers found different emission results from their experiments using coconut biodiesel blends. Liaquat et al. [21] investigated the utilization of coconut biodiesel blends B5 and B15 in a one cylinder 4-stroke diesel engine at various throttle settings. Both biodiesels produced higher exhaust gas temperatures and decreased $\mathrm{CO}$ emissions with a slight increase in $\mathrm{NO}_{\mathrm{x}}$ compared to CDF. Using the same type of diesel engine, Woo [22] and his colleagues studied coconut biodiesels of B25 and B40 at different injection timings. Their experimental results indicated that $\mathrm{NO}_{\mathrm{x}}$ formation was on average $8 \%$ and 12\% less than that of diesel for the B25 and B40 blends, respectively.

A fuel oil burner is a mechanical combustion machine that combines fuel oil with air in the proper amount before delivering the mixture to the ignition point in a combustion chamber [23]. The combustion of this mixture produces heat for application in industrial boilers to generate electricity and heater systems in buildings. The interest in oil burner technology is re-emerging due to the increase of fuel prices and the need to utilize waste oils, expand renewable fuels, and provide operational assurance against curtailments and fuel shortages. Despite the different findings and different methods used by researchers to obtain the combustion and emission characteristics of biodiesel, study on the utilization of CME biodiesel can be done extensively using an industrial oil burner rather than a 
diesel engine, as reported by other researchers. In this paper, the combustion and emission from the utilization of CME biodiesel at low blend ratios of B5, B15, and B25 were investigated as a preliminary evaluation of the suitability of applying this fuel in an oil burner at different fuel to air conditions. The combustor wall temperatures and exhaust emission concentrations from burning these biodiesel blends were compared with that of CDF.

\section{Methodology}

CME biodiesel was produced at the Combustion Laboratory, Faculty of Mechanical Engineering, Universiti Teknologi Malaysia using conventional laboratory apparatus. The transesterification process of coconut oil produces Coconut Methyl Ester (CME). There are three stages in the transesterification process, which includes the pre-treatment process, the transesterification process, and the post-treatment process. In the pre-treatment process, coconut oil was heated at $60^{\circ} \mathrm{C}$ at $400 \mathrm{rpm}$ for $1 \mathrm{~h}$ using a rotary evaporator to remove any moisture from the feedstock. Then the coconut oil was mixed with $25 \%$ by volume of methanol $(\mathrm{MeOH})$ and $1 \%$ by weight of Potassium Hydroxide $(\mathrm{KOH})$ to produce $\mathrm{CME}$ and glycerol in less than $2 \mathrm{~h}$ of reaction time at $60^{\circ} \mathrm{C}$ and $400 \mathrm{rpm}$ stirring speed. In the post-treatment process, the glycerol formed at the bottom layer was removed and the CME underwent the cleaning process, with distilled water being heated at $50{ }^{\circ} \mathrm{C}$ at various intervals to remove any unwanted impurities and remaining glycerol. Finally, the CME was reheated for 30 min using a rotary evaporator to remove any remaining water. The final product is a refined CME as shown in Figure 2.

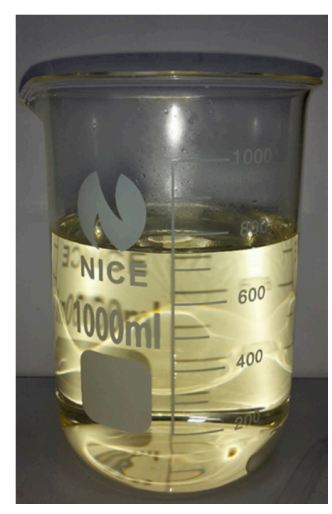

Figure 2. Refined Coconut Methyl Ester (CME).

\subsection{Fuel Blends and Physical Properties}

CME was mixed with CDF to produce B5, B15, and B25 biodiesel blends. A sample of each fuel blend was taken to test its physical properties in terms of density at $15{ }^{\circ} \mathrm{C}$, kinematic viscosity at $40{ }^{\circ} \mathrm{C}$, surface tension at $15{ }^{\circ} \mathrm{C}$, and gross calorific value. The testing was conducted at the Chemical Engineering Laboratory, Faculty of Chemical Engineering and Petroleum Engineering, Universiti Teknologi Malaysia. The volume and properties of diesel, CME, and their blends (B5, B15, and B25) are given in Table 1.

Table 1. The fuel properties of Conventional Diesel Fuel and CME biodiesel blends.

\begin{tabular}{cccccccc}
\hline \multirow{2}{*}{ Properties } & \multirow{2}{*}{ Standard } & \multirow{2}{*}{ Unit } & \multicolumn{7}{c}{ Fuels } \\
\cline { 4 - 8 } & & & CDF & B5 & B15 & B25 & B100 \\
\hline CME Volume & & $\mathrm{L}$ & 0 & 0.5 & 1.5 & 2.5 & - \\
Diesel Volume & & 10 & 9.5 & 8.5 & 7.5 & - \\
Density at $15^{\circ} \mathrm{C}$ & ASTM D941 & $\mathrm{kg} / \mathrm{m}^{3}$ & 830.1 & 831.5 & 834.3 & 837.1 & 858.2 \\
Kinematic Viscosity at $40^{\circ} \mathrm{C}$ & ASTM D445 & $\mathrm{mm}^{2} / \mathrm{s}$ & 3.5018 & 3.4678 & 3.3600 & 3.2594 & 2.8396 \\
Surface Tension at $15^{\circ} \mathrm{C}$ & ASTM D971 & $\mathrm{N} / \mathrm{m}$ & 0.0295 & 0.0296 & 0.0296 & 0.0297 & 0.0305 \\
Gross Calorific Value & ASTM D240 & $\mathrm{kJ} / \mathrm{kg}$ & 45,290 & 44,734 & 43,891 & 43,136 & 37,654 \\
\hline
\end{tabular}




\subsection{Experimental Set-Up}

Figure 3 shows the schematics of the experimental set-up for the combustion test. The set up included the Industrial Grade Light Oil Burner with a standard spray nozzle, a type-K thermocouple with a maximum temperature of $1200{ }^{\circ} \mathrm{C}$, a $1000 \mathrm{~mm}$ length open-ended mild steel combustion chamber insulated by cast cement, a Midi temperature data logger, an LCA 6000 air speed indicator, and a Horiba Enda 5000 gas analyzer. The burner was fixed at the front inlet of the combustion chamber to blow air and ignite the fuel. Eight thermocouples were placed along the wall of the top surface of the combustion chamber; each separated at an equidistance of $100 \mathrm{~mm}$. The thermocouples were connected to the Midi temperature data logger, which transformed the electric signal from the thermocouples to the temperature values along the combustion chamber wall. The Steinen standard nozzle was fixed to spray the fuel into the combustion chamber. For the spray nozzle, a single orifice nozzle that produces a finely atomized solid cone spray distribution pattern at an angle of $45^{\circ}$ was used. This nozzle sprays fuel at a pressure of 6.8 bar at a flow rate of $5.68 \mathrm{~L} / \mathrm{h}$, as shown in Figure 4 [24]. An emission chamber was connected to the exhaust of the combustion chamber to channel the emission from the combustion to the emission sensors. The sensor then sends an electrical signal to the Horiba Enda 5000 to display $\mathrm{NO}_{\mathrm{x}}, \mathrm{SO}_{2}$, and $\mathrm{CO}$ emission levels. An air speed indicator was used to set the appropriate air flow to fuel flow mixture ratios for all the different equivalence ratios.

The equivalence ratios used in this experiment were $0.8,1.0$, and 1.2. An equivalence ratio lower than stoichiometry $1.0(\Phi<1.0)$ is a lean mixture having more air and less fuel, while above 1.0 $(\Phi>1.0)$ is a rich mixture having less air and more fuel.

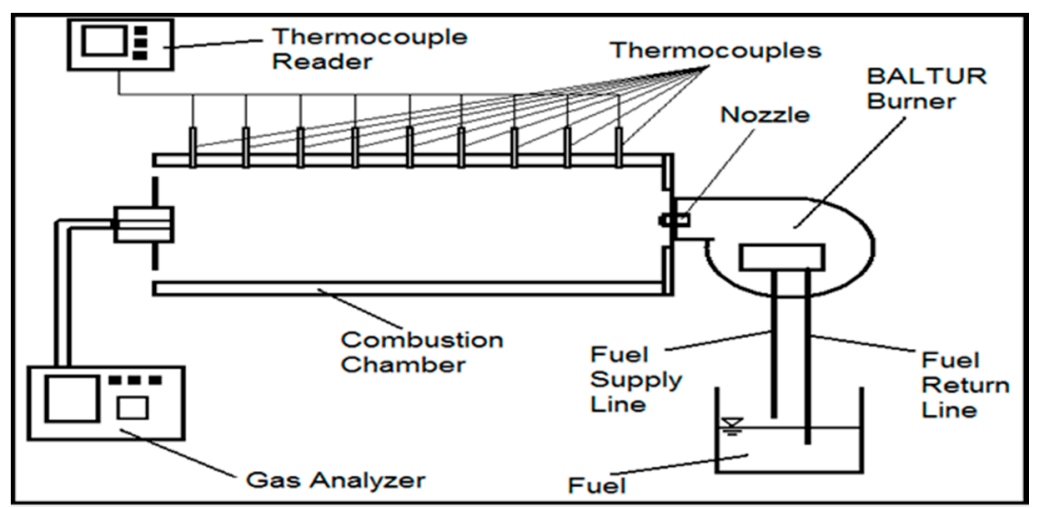

(a)

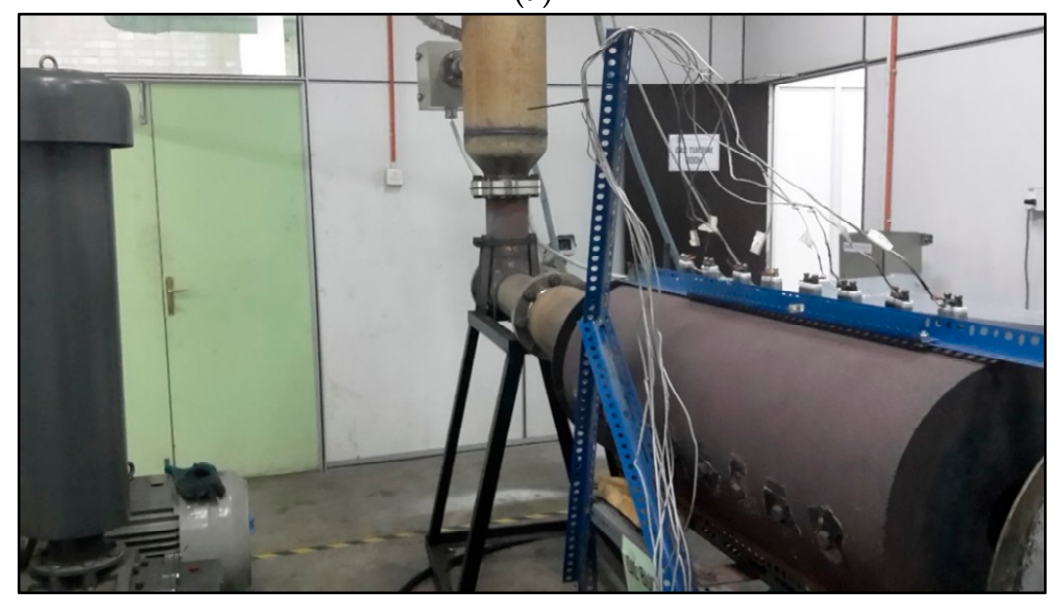

(b)

Figure 3. (a) Schematic diagram of combustion apparatus set up; (b) Combustion set up photo. 


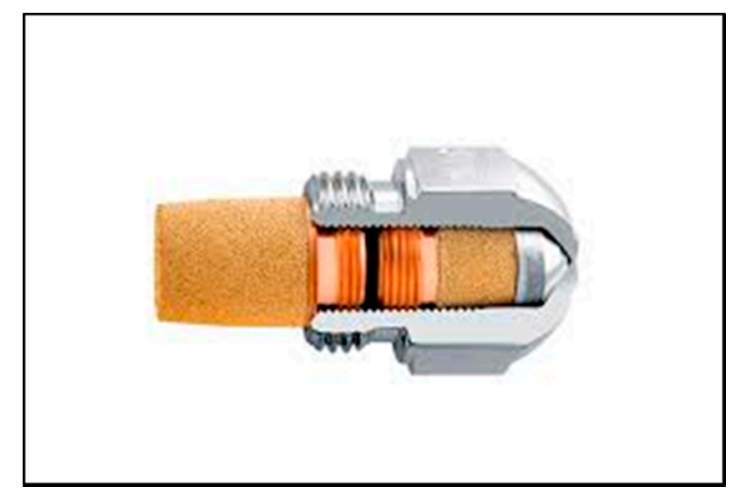

Figure 4. Industrial standard nozzle spray.

\section{Results and Discussion}

The experimental results for the combustion test include fuel physical properties, wall temperature profiles, and gaseous emissions. The wall temperature was based on the temperature detected by thermocouples along the combustion chamber wall and plotted against the thermocouple distance from the burner entrance to the combustion chamber. The gaseous emission concentrations for $\mathrm{NO}_{\mathrm{x}}$, $\mathrm{SO}_{2}$, and $\mathrm{CO}$ are plotted against the equivalence ratios for all the fuels tested.

\subsection{Fuel Properties}

The increase of CME content inside the blends with CDF increases the density and surface tension of the biodiesel blends but reduces the kinematic viscosity and calorific value of the fuels, as shown in Table 1. The increase in density is related to the high content of saturated fatty acid in coconut oil. Lauric acid and mystric acid are saturated fatty acid that make up the majority composition of the coconut oil. It has a single bond between its carbon chain atoms and hydrogen atoms. Such a configuration allows more hydrogen atoms to bond with carbon chain atoms and makes it heavier and denser than unsaturated fatty acid [25]. Thus, the increase of CME content contributes to the increase in biodiesel density. The increase of CME biodiesel surface tension is due to the presence of alkyl ester in biodiesel blends. It increases the intermolecular forces between fuel molecules, strengthening the weak intermolecular forces between hydrocarbon chains in diesel fuel [26]. Lower viscosity of CME biodiesel blends is related to the fuel carbon size and chain length of fatty acid, as explained in $[27,28]$. A long chain fatty acid leads to a bigger carbon size and also longer carbon chains (14 and above), which will increase fuel viscosity. The coconut oil composition is primarily made up of medium-chain fatty acid (MCFA), which has around 6 to 12 carbon atoms in a single chain. This reduces the viscosity of CME biodiesel. The calorific value of CME biodiesel was reduced due to the high oxygen content in biodiesel [29]. It improves the cetane number (an indication of combustion speed) of the fuel blend by reducing the ignition delay period and enhances faster fuel vaporization; thus combustion can take place at a lower temperature with low $\mathrm{NO}_{\mathrm{x}}$ formation [21].

\subsection{Wall Temperature Profile}

The fuel to air equivalence ratio affects the wall temperature profile for all CME biodiesel blends during combustion. By increasing the equivalence ratio from 0.8 to 1.0 and then to 1.2 , the combustion condition changed from a lean fuel mixture to stoichiometry and finally to a rich fuel mixture. Consequently, the volume of air flow decreased as the fuel flow rate increased. In all of the tested fuels (CME blends and diesel), the higher equivalence ratio $(\Phi=1.2)$ produced a higher wall temperature profile regardless of the type of fuel being used. This is because more fuel is burned at fuel rich mixture conditions, and consequently more heat is released during combustion [30]. Therefore, 
the overall temperature profile pattern for each fuel and its equivalence ratio is similar to each other as shown in Figure 5.

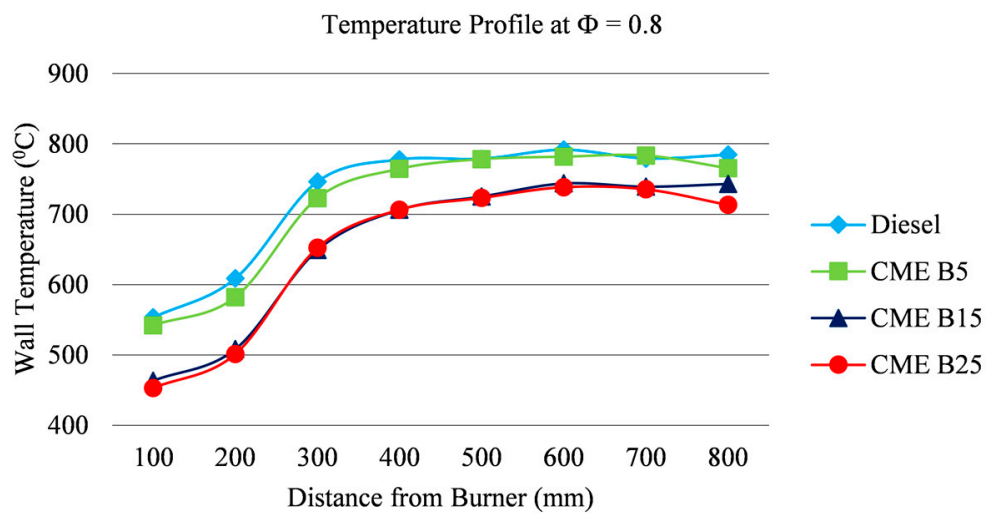

(a)

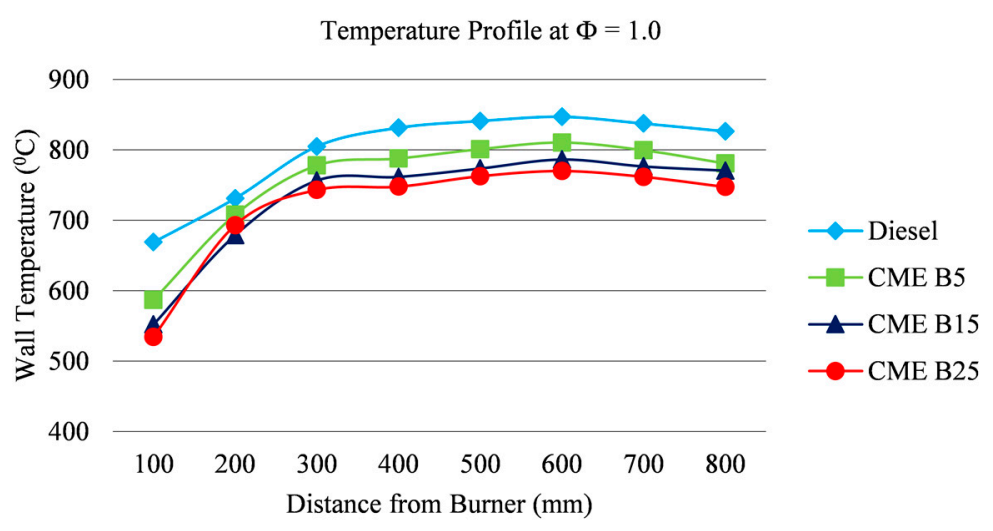

(b)

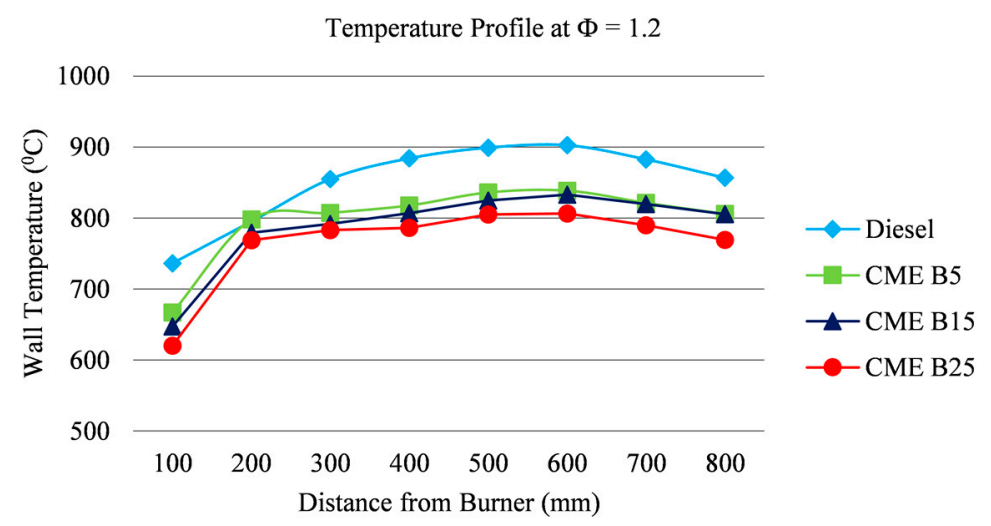

(c)

Figure 5. The temperature profile for all fuels at different equivalence ratios, (a) lean fuel mixture; (b) stoichiometry; (c) rich fuel mixture.

The temperature profile begins with the increase of the wall temperature at a distance of $100 \mathrm{~mm}$ to $500 \mathrm{~mm}$ from the burner inlet. The highest wall temperature is at a chamber length of $600 \mathrm{~mm}$ for all blends at all equivalence ratios. It is the point at where air and fuel are homogeneously combusted together to produce a higher amount of heat energy [30], thus indicating the size of the flame formed. The wall temperature then begins to drop at $700 \mathrm{~mm}$ until the end of the combustion chamber $(800 \mathrm{~mm})$, 
indicating that the flame is nearing its tip. Diesel has the highest wall temperature for each equivalence ratio followed by CME B5, CME B15, and CME B25. At stoichiometric conditions, the combustion of $\mathrm{CDF}$ produced a maximum wall temperature of $847.0^{\circ} \mathrm{C}$, followed by CME B5 at $810.5^{\circ} \mathrm{C}, \mathrm{CME} \mathrm{B} 15$ at $786.3^{\circ} \mathrm{C}$, and $\mathrm{CME} \mathrm{B25}$ at $770.0^{\circ} \mathrm{C}$. The reduction in the highest wall temperature as compared to $\mathrm{CDF}$ for CME B5 is 4.31\%, followed by CME B15 at 7.17\% and CME B25 at $9.09 \%$. These peak temperatures occur at the middle section of the combustor due to the high heat intensity at this point. The increase of CME content in diesel blends reduces the calorific value of biodiesel fuel blends, causing the wall temperature to be lower than that of CDF.

\subsection{Gaseous Emission}

Gaseous emissions such as $\mathrm{NO}_{\mathrm{x}}, \mathrm{SO}_{2}$, and $\mathrm{CO}$ are toxic emissions that are harmful to the environment and human health at high concentrations. Hence, it is important to identify the emissions from the combustion of coconut oil-based biodiesel blend to determine its suitability as a replacement for fossil fuels. This section provides the comparison of emission concentrations for CME blends with $\mathrm{CDF}$ at all equivalence ratios.

\subsection{1. $\mathrm{NO}_{\mathrm{x}}$ Emission}

The concentration of $\mathrm{NO}_{\mathrm{x}}$ emission for each fuel tested (CDF and CME blends) at different equivalence ratios are shown in Figure 6. The graphs showed that diesel and CME blends exhibit the same $\mathrm{NO}_{\mathrm{x}}$ trend. At stoichiometric conditions, $\mathrm{CDF}$ emits the highest $\mathrm{NO}_{\mathrm{x}}$ emission of $61 \mathrm{ppm}$, followed by CME B5 at 58 ppm, CME B15 at 51 ppm, and CME B25 at 50 ppm. Figure 6 also shows that, in the lean region $(\Phi<1)$, increasing the equivalence ratio increases the $\mathrm{NO}_{\mathrm{x}}$ emission, which reaches peak value at the equivalence ratio of $1.0(\Phi=1)$ and then decreases in the rich region $(\Phi>1)$. At fuel lean mixtures, $\mathrm{NO}_{\mathrm{x}}$ increases due to thermal effect from the increasing temperature, and the presence of excess oxygen allows the oxidation of nitrogen in the atmosphere to form $\mathrm{NO}$, contributing to the formation of $\mathrm{NO}_{\mathrm{x}}$. The increase of $\mathrm{NO}$ from the thermal effect continues until it reaches stoichiometric conditions. In the fuel rich mixture, the content of air is less, thus reducing the reaction of nitrogen with oxygen to produce NO.

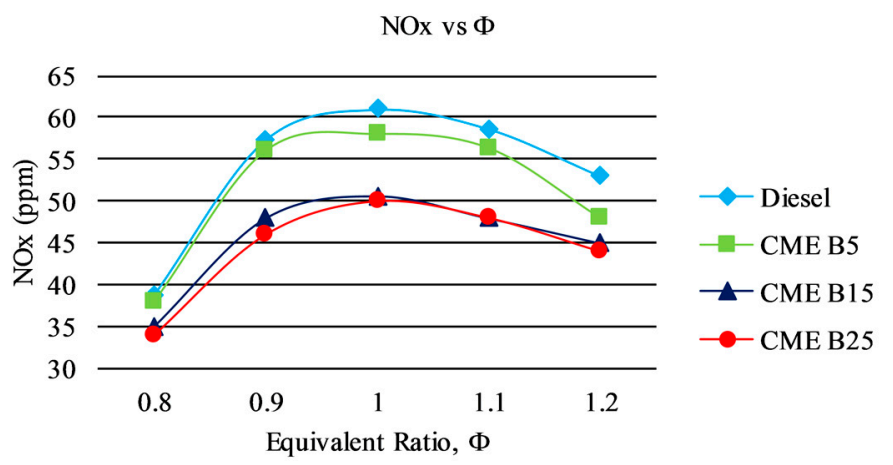

Figure 6. The $\mathrm{NO}_{\mathrm{x}}$ emission profile for $\mathrm{CDF}$ and different $\mathrm{CME}$ blends.

The increase of $\mathrm{CME}$ content in diesel blends reduces the production of $\mathrm{NO}_{\mathrm{x}}$ during combustion. CME B5 produces $4.92 \%$, CME B15 produces $16.39 \%$, and CME B25 produces $18.03 \%$ lower $\mathrm{NO}_{\mathrm{x}}$ than $\mathrm{CDF}$ does at stoichiometric conditions. The higher cetane numbers of CME shorten the ignition time during fuel spray. Moderate temperatures inside the chamber can restrict the reaction of nitrogen with oxygen to form $\mathrm{NO}_{\mathrm{x}}$ which requires high temperatures to be produced. The reduction of $\mathrm{NO}_{\mathrm{x}}$ during combustion can be related to fuel properties. Coconut-based biodiesel is comprised of shorter hydrocarbon chains than conventional diesel. The medium carbon chain length will result in a lower flame temperature and thus less NO formation. 


\subsection{2. $\mathrm{SO}_{2}$ Emission}

Figure 7 shows the $\mathrm{SO}_{2}$ emission for each tested fuel at different equivalence ratios. At stoichiometric conditions, $\mathrm{CDF}$ produces the highest $\mathrm{SO}_{2}$ emission of $14 \mathrm{ppm}$, followed by CME $\mathrm{B} 5$ at $12 \mathrm{ppm}, \mathrm{CME} B 15$ at $7 \mathrm{ppm}$, and CME B25 at $6 \mathrm{ppm}$. In the lean region $(\Phi<1)$, by increasing the equivalence ratio, $\mathrm{SO}_{2}$ increases to reach its peak value at stoichiometric conditions $(\Phi=1)$ and then decreases in the rich region $(\Phi>1)$. The formation of $\mathrm{SO}_{2}$ increases when the temperature and oxygen concentrations are high [31,32]. Under the lean fuel mixture $(\Phi<1)$, the temperature is high and has excess air, which increases the formation of $\mathrm{SO}_{2}$. At rich mixtures $(\Phi>1)$, the temperature is greater than in the lean mixture but there is less air; thus less $\mathrm{SO}_{2}$ is formed. At stoichiometric conditions, CME B5 produces 7.69\%, CME B15 46.15\%, and CME B25 53.85\% less $\mathrm{SO}_{2}$ than does CDF. CME has less sulphur content than diesel, which further reduces the formation of $\mathrm{SO}_{2}$ for all combustion conditions.

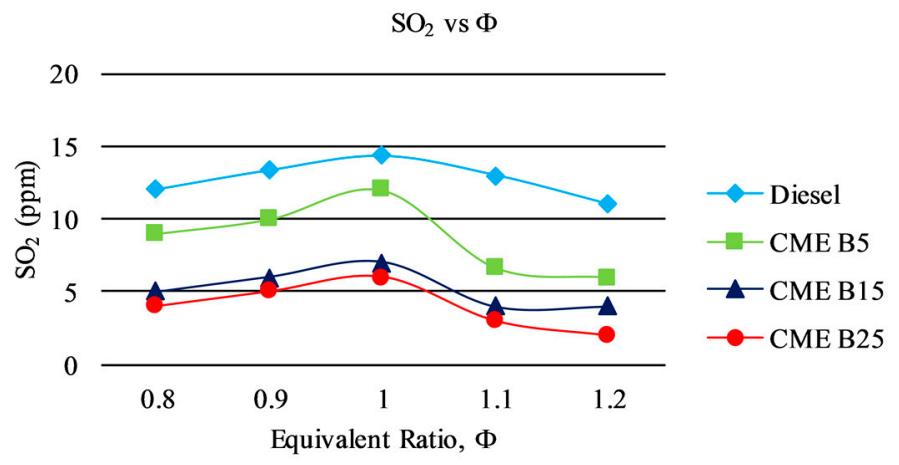

Figure 7. The $\mathrm{SO}_{2}$ emission profile for $\mathrm{CDF}$ and different $\mathrm{CME}$ blends.

\subsubsection{CO Emission}

Figure 8 shows the emission of $\mathrm{CO}$ for $\mathrm{CDF}$ and $\mathrm{CME}$ blends for each equivalence ratio. At $\Phi=0.8$, by increasing the equivalence ratio, $\mathrm{CO}$ emission decreases to reach its lowest value at stoichiometric conditions $(\Phi=1)$ and then rises sharply in rich conditions $(\Phi>1)$. At stoichiometric conditions $(\Phi=1)$, CDF produces 21 ppm of CO emission, followed by CME B5 and B15 at 2 ppm and CME B25 at $1 \mathrm{ppm}$, resulting in a 90.48\% reduction for CME B5 and CME B15 and a $95.24 \%$ reduction for CME B25. CO emission concentration is highest during an incomplete combustion of fuel in a low oxygen environment. The fuel rich mixture conditions during combustion promote higher formation of $\mathrm{CO}$ due to high fuel consumption and inadequate air supply. The increasing content of CME in diesel fuel reduces the $\mathrm{CO}$ emission significantly as biodiesel contains between 10 to 12 percent more oxygen than $\mathrm{CDF}[33,34]$. In biodiesel, the extra oxygen content promotes the conversion of $\mathrm{CO}$ to $\mathrm{CO}_{2}$, resulting in complete combustion of the fuel.

CO vs $\Phi$

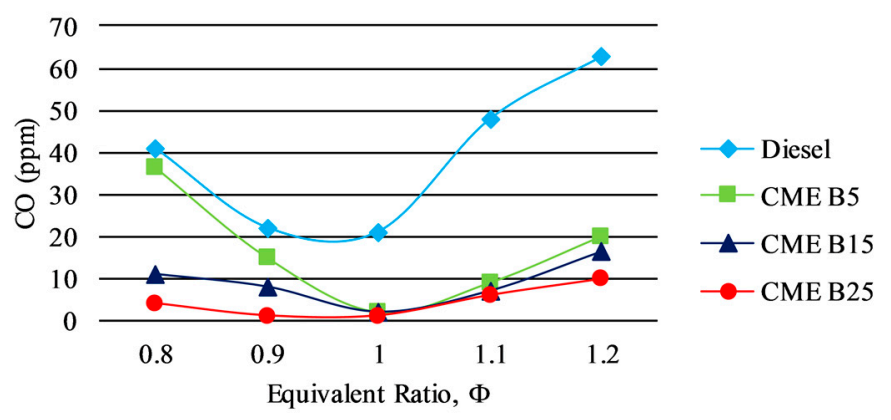

Figure 8. The $\mathrm{CO}$ emission profile for $\mathrm{CDF}$ and different $\mathrm{CME}$ blends. 


\section{Conclusions}

The experiments regarding the combustion and emission characteristics of CME biodiesel blends in a liquid fuel burner were conducted and compared with CDF at various equivalence ratios. Fuel properties such as density, kinematic viscosity, surface tension, and calorific value were measured for each fuel blends. Then, all fuels were combusted at different equivalence ratios to obtain the wall temperature, $\mathrm{NO}_{x}, \mathrm{SO}_{2}$, and $\mathrm{CO}$ emission profiles. The results indicated that, by increasing the $\mathrm{CME}$ content in diesel blend, the density and surface tension increased while the kinematic viscosity and calorific value decreased. The chemical composition of CME altered the fuel properties of diesel, which resulted in the CME biodiesel to have different fuel properties. The chemical composition of CME also improved the fuel combustion efficiency at lower temperatures. The increase of CME content in diesel blends reduced the emissions of $\mathrm{NO}_{\mathrm{x}}, \mathrm{SO}_{2}$, and $\mathrm{CO}$. The results of the study can also be concluded with the following remarks:

- For all equivalence ratios, the CME biodiesel blends combust at lower temperatures than CDF.

- An increase in CME content reduces the combustion temperature.

- An increase in the fuel consumption results in a decrease in the air volume, which generates more heat energy during the combustion.

Acknowledgments: The authors would like to thank the Ministry of Higher Education of Malaysia and the Research Management Center and Innovation, Universiti Malaysia Perlis for awarding the research grant under the Fundamental Research Grant Scheme (9003-00537). The authors would also like to thank the Research Management Center and Faculty of Mechanical Engineering, Universiti Teknologi Malaysia for knowledge transfer and providing the research facilities and space to undertake this research study under grant (12J21).

Author Contributions: The contributions of each authors are as follows: Muhammad Syahiran Abdul Malik and Ashrul Ishak Mohamad Shaiful provided the impetus for this work, obtained the experimental data, analyzed the numerical results and drafted the manuscript. Mohammad Nazri Mohd Jaafar, Mohd Shuisma Mohd. Ismail, and Amirah Mohamad Sahar provided insights that led to some of the distinctions between equations being highlighted and worked on rewrites and clarifications. All authors have read and approved the final manuscript.

Conflicts of Interest: The authors declare no conflict of interest.

\section{References}

1. Puigjaner, L.; Pérez-Fortes, M.; Laínez-Aguirre, J. Towards a Carbon-Neutral Energy Sector: Opportunities and Challenges of Coordinated Bioenergy Supply Chains-A PSE Approach. Energies 2015, 8, 5613-5660. [CrossRef]

2. Golledge, N.R.; Kowalewski, D.E.; Naish, T.R.; Levy, R.H.; Fogwill, C.J.; Gasson, E.G.W. The Multi-Millennial Antarctic Commitment to Future Sea-Level Rise. Nature 2015, 526, 421-425. [CrossRef] [PubMed]

3. Argawal, A.; Gupta, A.K.; Pandey, A. Novel Combustion Concepts for Sustainable Energy Development; Springer: New Delhi, India, 2014.

4. Chen, J.; Wang, W.H.; Liu, T.W.; Wu, F.H.; Zheng, H.L. Photosynthetic and Antioxidant Responses of Liquidambar Formosana and Schimasuperba Seedlings to Sulfuric-Rich and Nitric-Rich Simulated Acid Rain. Plant Physiol. Biochem. 2013, 64, 41-51. [CrossRef] [PubMed]

5. Aslan, S.; Uzkeser, M.; Seven, B.; Gundogdu, F.; Acemoglu, H.; Aksakal, E.; Varoglu, E. The Evaluation of Myocardial Damage in 83 Young Adults with Carbon Monoxide Poisoning in the East Anatolia Region in Turkey. Hum. Exp. Toxicol. 2006, 25, 439-446. [CrossRef] [PubMed]

6. Knothe, G.; Dunn, R.O.; Bagby, M.O. Biodiesel: The Use of Vegetable Oils and Their Derivatives as Alternative Diesel Fuels. In Fuels and Chemicals from Biomass; Saha, B.C., Woodward, J., Eds.; American Chemical Society (ACS): Washington, DC, USA, 1997; pp. 172-208.

7. Xie, H.; Song, L.; Xie, Y.; Pi, D.; Shao, C.; Lin, Q. An Experimental Study on the Macroscopic Spray Characteristics of Biodiesel and Diesel in a Constant Volume Chamber. Energies 2015, 8, 5952-5972. [CrossRef]

8. Ejikeme, P.M.; Anyaogu, I.D.; Ejikeme, C.L.; Nwafor, N.P.; Egbuonu, C.A.C.; Ukogu, K.; Ibemesi, J.A. Catalysis in Biodiesel production by Transesterification Processes-An Insight. J. Chem. 2010, 7, 1120-1132. [CrossRef] 
9. Magin, L.; Rodríguez-Fernández, J.; Agudelo, J.R. Diesel Particulate Emissions from Used Cooking Oil Biodiesel. Bioresour. Technol. 2008, 99, 731-740.

10. Mustafa, C.; Van Gerpen, J.H. Comparison of Engine Performance and Emissions for Petroleum Diesel Fuel, Yellow Grease Biodiesel, and Soybean Oil Biodiesel. Trans. ASAE 2003, 46, 937.

11. Mohd Jaafar, M.N.; Eldrainy, Y.A.; Mat Ali, M.F.; Wan Omar, W.Z.; MohdHizam, M.F.A. Combustion Performance Evaluation of Air Staging of Palm Oil Blends. Environ. Sci. Technol. 2012, 46, 2445-2450. [CrossRef] [PubMed]

12. Ja'afar, M.N.M.; Omar, W.Z.W.; Rahim, M.R.; Azmi, I.; Abdullah, M.H. Study on Combustion Performance of Palm Oil Biodiesel Blend. J. Teknol. 2014, 69, 127-131.

13. Ganjehkaviri, A.; Jaafar, M.N.M.; Hosseini, S.E.; Musthafa, A.B. Performance Evaluation of Palm Oil-Based Biodiesel Combustion in an Oil Burner. Energies 2016, 9, 97. [CrossRef]

14. Raghavan, K. Biofuels from Coconuts; Fuels from Agriculture in Communal Technology (FACT) Foundation: Wageningen, The Netherlands, 2010.

15. Price Policy for the 2016 Season Copra. Commission for Agricultural Costs and Prices; Ministry of Agriculture of India: New Delhi, India, 2015.

16. Cloin, J. Coconut Oil as a Biofuel in Pacific Islands: Challenges and Opportunities; South Pacific Applied Geoscience Commission: Suva, Fiji, 2005.

17. Saifuddin, N.; Fazlili, A.; Kumaran, P.; Pei-Jua, N.; Priathashini, P. The Production of Biodiesel and Bio-kerosene from Coconut Oil Using Microwave Assisted Reaction. Earth Environ. Sci. 2016, 32, 12039-12043. [CrossRef]

18. Suryanto, A.; Suprapto, S.; Mahfud, M. The Production of Biofuels from Coconut Oil Using Microwave. Modern Appl. Sci. 2015, 9, 93. [CrossRef]

19. Llamas, A.; García-Martínez, M.J.; Al-Lal, A.M.; Canoira, L.; Lapuerta, M. Biokerosene from Coconut and Palm Kernel Oils: Production and Properties of Their Blends with Fossil Kerosene. Fuel 2012, 102, 483-490. [CrossRef]

20. Giles, V. Pacific Regional Workshop on Biofuels: Opportunities and Implications for Sustainable Livelihoods in Pacific Island Countries; Pacific Regional Workshop: Nadi, Fiji, 2008.

21. Liaquat, A.M.; Masjuki, H.H.; Kalam, M.A.; Fattah, I.R.M.; Hazrat, M.A.; Varman, M.; Mofijur, M.; Shahabuddin, M. Effect of Coconut Biodiesel Blended Fuels on Engine Performance and Emission Characteristics. Procedia Eng. 2013, 56, 583-590. [CrossRef]

22. Woo, C.; Kook, S.; Hawkers, E.; Rogers, P.L.; Marquis, C. Engine Combustion and Emission of Coconut Oil Based Biodiesel and Diesel Blends. In Proceedings of the 19th Australasian Fluid Mechanics Conference, Melbourne, Australia, 8-11 September 2014.

23. Salleh, M.M.N. Study on the Performance of Envo Diesel in a Combustion System. Master's Thesis, Universiti Teknologi Malaysia, Skudai, Malaysia, 2015.

24. Steinen Nozzle Catalog. Industrial Mining Oil Burner; Steinen Mfg. Co.: Parsippany, NJ, USA, 2016.

25. Myers, R.L. The Basics of Chemistry, 1st ed.; Greenwood Pub Group: Santa Barbara, CA, USA, 2003.

26. Ramalho, E.F.S.M.; Filho, J.R.C.; Albuquerque, A.R.; de Oliveira, S.F.; Cavalcanti, E.H.S.; Stragevitch, L.; Santos, I.M.G.; Souza, A.G. Low Temperature Behavior of Poultry Fat Biodiesel: Diesel Blends. Fuel 2012, 93, 601-605. [CrossRef]

27. Refaat, A.A. Correlation between the Chemical Structure of Biodiesel and Its Physical Properties. Int. J. Environ. Sci. Technol. 2009, 6, 677-694. [CrossRef]

28. Puhan, S.; Saravanan, N.; Nagarajan, G.; Vedaraman, N. Effect of Biodiesel Unsaturated Fatty Acid on Combustion Characteristics of a DI Compression Ignition Engine. Biomass Bioenergy 2016, 34, 1079-1088. [CrossRef]

29. Sivaramakrishnan, K. Determination of Higher Heating Value of Biodiesels. Int. J. Eng. Sci. Technol. 2011, 3, 7981-7987.

30. Musthafa, A.B. Study on the Performance of Palm Methyl Ester in a Combustion System. Master's Thesis, Universiti Teknologi Malaysia, Skudai, Malaysia, 2015.

31. Croiset, E.; Thambimuthu, K.V. NO and SO Emissions from O/CO Recycle Coal Combustion. Fuel 2016, 80, 2117-2121. [CrossRef]

32. Hasenberg, L.; Bender, R. Corrosion Handbook: Corrosive Agents and Their Interaction with Materials: V. 10: Sulfur Dioxide, Sodium Sulfate; Wiley-VCH Verlag GmbH: Weinheim, Germany, 2008. 
33. Gumus, M.; Kasifoglu, S. Performance and Emission Evaluation of a Compression Ignition Engine Using a Biodiesel (Apricot Seed Kernel Oil Methyl Ester) and Its Blends with Diesel Fuel. Biomass Bioenergy 2010, 34, 134-139. [CrossRef]

34. Habibullah, M.; Rizwanul Fattah, I.M.; Masjuki, H.H.; Kalam, M.A. Effects of Palm-Coconut Biodiesel Blends on the Performance and Emission of a Single-Cylinder Diesel Engine. Energy Fuels 2015, 29, 734-743. [CrossRef] 